\title{
Impact of Municipal Solid Waste Landfill on Environment - A Case Study
}

\author{
Magdalena Daria Vaverková '*, Dana Adamcová', Jan Zloch', Maja Radziemska², \\ Agnieszka Boas Berg ${ }^{3}$, Stanislava Voběrková4 Alžbeta Maxianová'
}

1 Department of Applied and Landscape Ecology, Faculty of AgriSciences, Mendel University in Brno, Zemědělská 1, 61300 Brno, Czech Republic

2 Department of Environmental Improvement, Faculty of Civil and Environmental Engineering, Warsaw University of Life Sciences, Nowoursynowska 159, 02-776 Warsaw, Poland

3 Shada BV, Kanaal Noord 350, NL-7323 Am Apeldoorn, Holland

${ }^{4}$ Department of Chemistry and Biochemistry, Faculty of Agronomy, Mendel University in Brno, Zemědělská 1, 613 00, Czech Republic

* Corresponding author's e-mail: magda.vaverkova@uake.cz

\begin{abstract}
Landfill is the oldest and the most common form of removal and disposal of waste, constituting the final disposal method of municipal solid waste (MSW). It is well known that the impact of MSW landfills can cause pollution of all environmental components. The negative environmental impact of landfills can be reduced by applying protection technologies and appropriate solid waste management technologies. The present study undertook monitoring of the Štěpánovice MSW landfill influence on the environment. The spatial characteristics of the area influenced by the landfill and the possible impact of leachate using phytotoxicity tests were carried out. The landfill itself is engineered, with bottom liner and leachate and landfill gas collection and treatment system. The landfill has not had any direct and significant influence on the surrounding environment and water quality so far.
\end{abstract}

Keywords: landfill influence, waste disposal site, contamination, phytotoxicity, landfill leachate

\section{INTRODUCTION}

Each year, about $10 \cdot 10^{3} \mathrm{Kg}$ of municipal solid waste (MSW) is produced globally (Shu et al., 2018). As the final method disposal of MSW, landfill, is the oldest and the most common form of removal and disposal of waste (Koda et al., 2015). Waste management is a civilizational problem (Wolny-Koładka and Malinowski, 2015) and landfills have been widely applied due to a number of advantages, including simplicity, low investment, large handling capacity and low operating cost ( $\mathrm{Li}$ et al., 2017). Some studies indicated that almost $95 \%$ of MSW was disposed of by landfilling worldwide (Ghosh et al., 2015); in the European Union (EU), most of the member states dispose of more than $50 \%$ of their waste in landfills (Cuartas et al., 2017). However, with the pro- gress of urbanization and the residents' demands of higher living environment quality, the pollution of landfill sites has increasingly attracted attention in the world, because landfill contains a great deal of potential toxic compounds, some of which may threaten the safety of the surrounding environment. It is known that the impact of MSW landfills can cause pollution of all environmental components (Makarenko and Budak, 2017). In recent years, some researchers studied the influence of landfill sites on the groundwater. For instance, El-Salam and Abu-Zuid (2015) analysed the environmental impacts associated with MSW landfilling, leachate and groundwater quality near the landfills in Egypt. Nagarajan et al. (2012) studied the possible impact of leachate percolation on the groundwater quality. Another study, provided by Koda et al. (2017) assessed the 
groundwater quality in a landfill and a waste management site, with special regard to the levels of organic pollution. There have been studies in the literature reporting more generally the influence of landfill sites on nearest surrounding. For example, Gworek et al. (2015) focused on assessing the influence of a 35-year-old MSW landfill on the environmental mercury pollution in the soil profile, groundwater, and the plants. Palmiotto et al. (2014) conducted integrated risk assessment for emissions of hazard compounds and odour nuisance to describe the environmental quality in the landfill proximity.

The negative environmental impact of landfills can be reduced by applying protection technologies in landfill design, such as the use of an appropriate impermeable material for bottom and top capping (Dajić et al., 2016; Cuartas et al., 2017). These negative environmental impacts must be controlled both during the operational phase of a landfill, and post-closure (known as the 'aftercare' period) until they no longer pose an unacceptable risk to the environment. Our research team has been involved in the investigation of the environmental problems of contaminants produced and released from landfill facilities. The present study undertook the monitoring of the Štěpánovice MSW landfill influence on the environment in order to: (i) study the spatial characteristics of the area influenced by the landfill, (ii) better understand the possible impact of leachate using phytotoxicity tests, (iii) and to assess landfill influence on water quality. The research results provide scientific information for protecting and managing the environment in the landfill surrounding and similar areas, and we hope it provides a good example for further environmental research.

\section{MATERIAL AND METHODS}

The research focuses on several characteristics describing the MSW Štěpánovice: historical development of the cadastre illustrated using maps, analysis of the environmental conditions and landfill reclamations. The research likewise focuses on the assessment of the phytotoxicity of the leachate and waters from the active body of MSW Štěpánovice landfill. The research involves assessing the correlation between the toxicity of the tested water samples and the precipitation volumes in the given area as well as the resulting environmental conditions.

\section{Study area}

The study area is located in the Pilsen Region (Štěpánovice, $\left.49^{\circ} 26^{\prime} 15.934^{\prime \prime} \mathrm{N}, 13^{\circ} 16^{\prime} 55.352^{\prime \prime} \mathrm{E}\right)$, western part of the Czech Republic (Figure 1). It is being used for disposal of mixed municipal waste. The landfill is formed by three sub-landfills: landfill A (closed in 2003, area of $8,750 \mathrm{~m}^{2}$ ); landfill B (working from 2003-2016, area of 26,000 m²); landfill $\mathrm{C}$ (still in operation). The total volume of both (A, B) parts of the landfill is $289,000 \mathrm{~m}^{3}$ (Heralová, 2017; Adamcová et al., 2017).

Every day, up to $37.5 \cdot 10^{3} \mathrm{~kg}$ of waste is authorized for landfilling. The disposed waste includes: municipal solid waste, non-hazardous

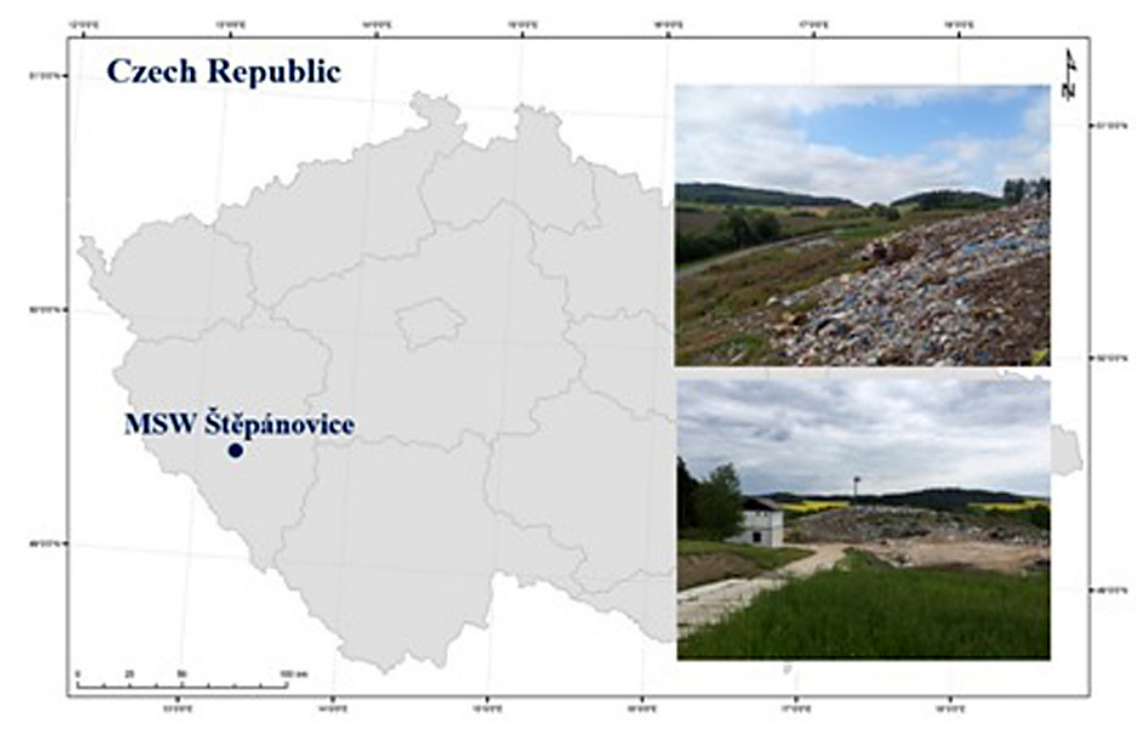

Figure 1. Location of the landfill 
wastes and the material for landfill cover. Wastes may include scraps of paper, plastics and metals, packing, spent tires, textile products, building materials, ashes from municipal solid waste incinerators, polluted terrain from environment reclamation, etc. (Heralová, 2017) (the amount of waste landfilled in years 2015 and 2016 is presented in Figure 2). In 2015, a total of $18,291.3 \times 10^{3} \mathrm{~kg}$ of waste was deposited on the landfill and $16,142.9 \times 10^{3} \mathrm{~kg}$ of wastes in 2016 . In last years, the production of landfilled waste has been reduced.

The landfill site is located over an impermeable natural clay layer; the bottom and side boundaries may vary according to the period of cultivation; however, they generally include several protective layers, such as a compact clay layer $(100 \mathrm{~cm})$, geotextile membranes, gravel $(50 \mathrm{~cm})$, geomembranes $(1.5 \mathrm{~mm})$ non-woven fabric $\left(1200 \mathrm{~g} / \mathrm{m}^{2}\right)$, pulper products. The landfill covers (top and side) are formed by a waste layer to stabilize the surface, drainage systems, compact clay $(20 \mathrm{~cm})$, soil and a vegetative soil layer (up to $100 \mathrm{~cm}$ ). A grassy mantle and/or forestation with local vegetation will complete the recovery of the environment after closing of each parcel. The systems for leachate treatment, and gas recovery, collection and treatment are in operation. The landfill is situated in the north part of widely opened valley directed towards W-E. The landfill is surrounded to the $\mathrm{N}$ and $\mathrm{S}$ by a vegetation belt, predominantly comprising Pinus sylvestris. The hilly landscape in the western part of the study area is used for agriculture, similarly to the eastern lowland (Adamcová et al., 2017).

\section{The history of solid municipal waste landfill Štěpánovice}

The development of the Štěpánovice landfill cadastre is illustrated using historical maps between 1950 and the present. The site has been described in terms of cadastral changes. The landfill is located in the cadastres of Dehtín and Štěpánovice municipalities. Figure 3 shows the borderline between municipal cadastres using a red line. The landfill is located at the Šumava foothills.

\section{Natural conditions}

The environmental conditions around the landfill were described in terms of their pedological, geological and geomorphological features. The characteristics of the environmental conditions also comprise the description of protected landscape areas and territorial systems of ecological stability. The territorial systems of ecological stability are defined by the Act No. 114/1992 Coll., on Nature and Landscape Protection as a mutually integrated complex of natural and altered, although nearly natural, ecosystems which maintain natural stability. The aim of the territorial systems of ecological stability is to set up a network of environmentally relatively stable locations, preservation or recovery of the landscape genetic resources, as well as preservation or bolstering of the diversity of indigenous species and their communities (biodiversity). Setting up territorial systems of ecological stability is, by law, a public interest shared by the owners of the land, the municipality and the state.

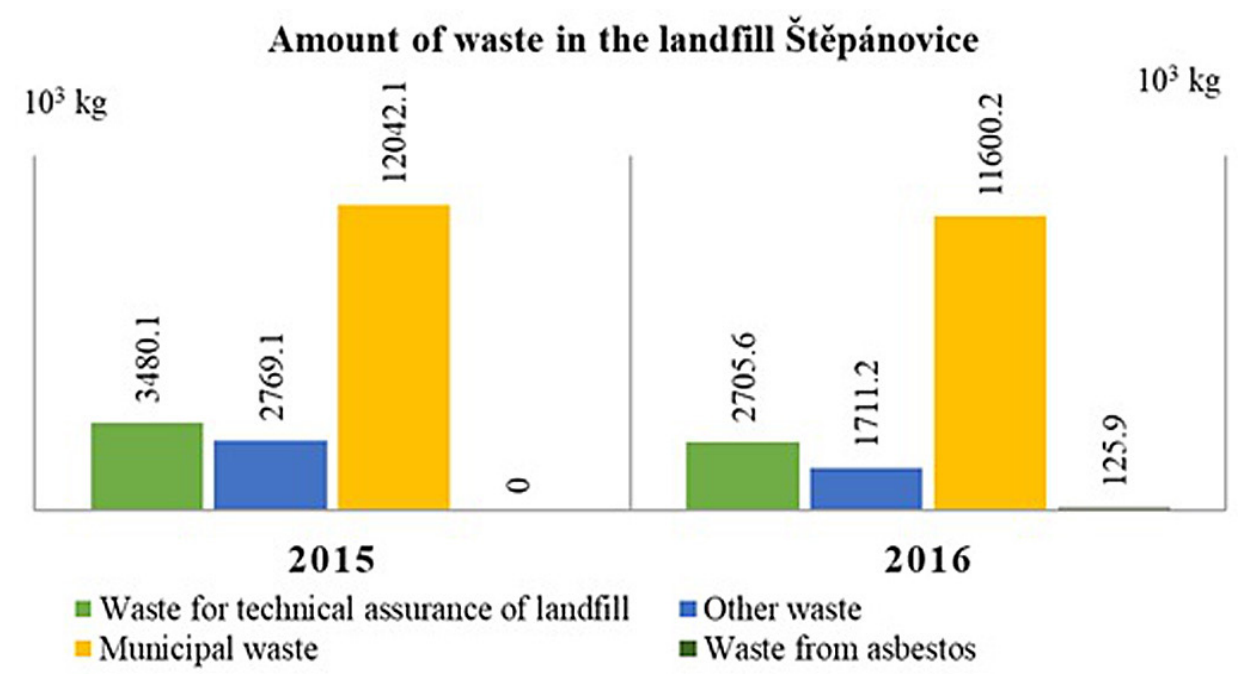

Figure 2. Amount of waste in the years 2015-2016 


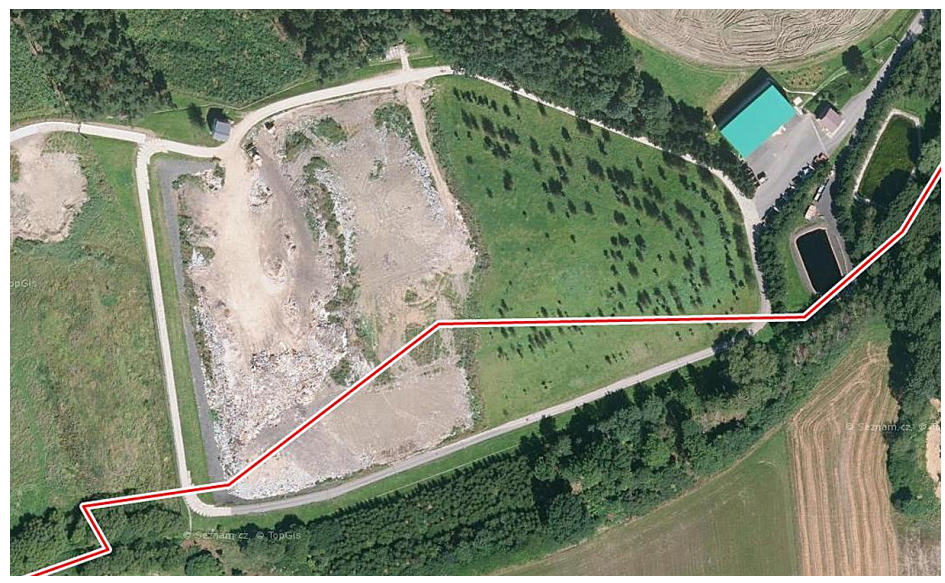

Figure 3. The map of land borders (Heralová, 2017)

\section{Reclamation}

Closing and reclamation of a landfill is defined by the CSN 838035 standard as the aggregate of measures and works carried out at the landfill having filled its volume and finished dumping waste in compliance with the conditions set by the standard. The binding measures include: regulating the shape of the landfill body, closure and reclamation of the surface with subsequent maintenance of the closed landfill including implementing prescribed monitoring in association with the set approved integrated pollution prevention and control (IPPC). Landfill closure potentially prevents the pollution or negative influence on individual environmental components in close vicinity to the landfill. Reclamation results in the best possible securing and setting up of suitable technical conditions for successive utilisation of the given site and apt incorporation of the reclamation site into the surrounding countryside.

The technical and biological reclamation at the landfill was carried out in 2009. The research focused only on the biological reclamation between 2009 and 2017. The course of biological reclamation was captured in photographs over the specified years (Vaverková and Adamcová, 2018).

\section{Leachate toxicity monitoring}

Leachate from the landfill is a potential source of environmental pollution that can for instance have a toxic effect on water sources, animals or plants. Leachate is contaminated with heavy metals which can represent a problem for the environment and the health of its inhabitants. Heavy metals are not biodegradable and have a toxic impact on living organisms. As a result, there is a potential risk of heavy metal pollution and their incorporation into the food chain. It is therefore essential to monitor the quality of leachate. Pursuant to legislation, the leachate, the underground and surface water by the landfill undergo regular monitoring twice a year. As part of the research, the samples of leachate from the leachate sink were taken. The collection of samples was made once a month between April and October 2016 (7 months). The leachate sample was collected once, directly from the active body of the landfill. Precipitation in the given period (mm) was monitored simultaneously. Figure 4 shows the leachate collection sites. Upon collection of leachate, the values below were measured at the site: $\mathrm{pH}$, current temperature $\left({ }^{\circ} \mathrm{C}\right)$ and conductivity $(\mathrm{mS} / \mathrm{m})$. Sterile 2 litre sample containers were used to collect the leachate samples and transport them for analysis in a laboratory under the stipulated conditions of $4^{\circ} \mathrm{C}$ temperature and in the dark. Every leachate sample was subsequently subjected to a toxicity test. A semi-chronic test using Sinapis alba $\mathrm{L}$ seeds was used. The main reason for carrying out the test was ascertaining the growth inhibition or leachate stimulation on plants and their potential to irrigate crops. The principle of the test is monitoring Sinapis alba L. reactions in the initial stages of development (sprouting and the growth of roots) in the tested solution of the sample, compared to the nutrient solution (Heralová, 2017).

\section{Phytotoxicity test of leachate}

In order to assess the toxicity of landfill leachate, test organism, i.e. white mustard (Sinapis alba L.) was used. The phytotoxicity of the leachate was determined by calculating 

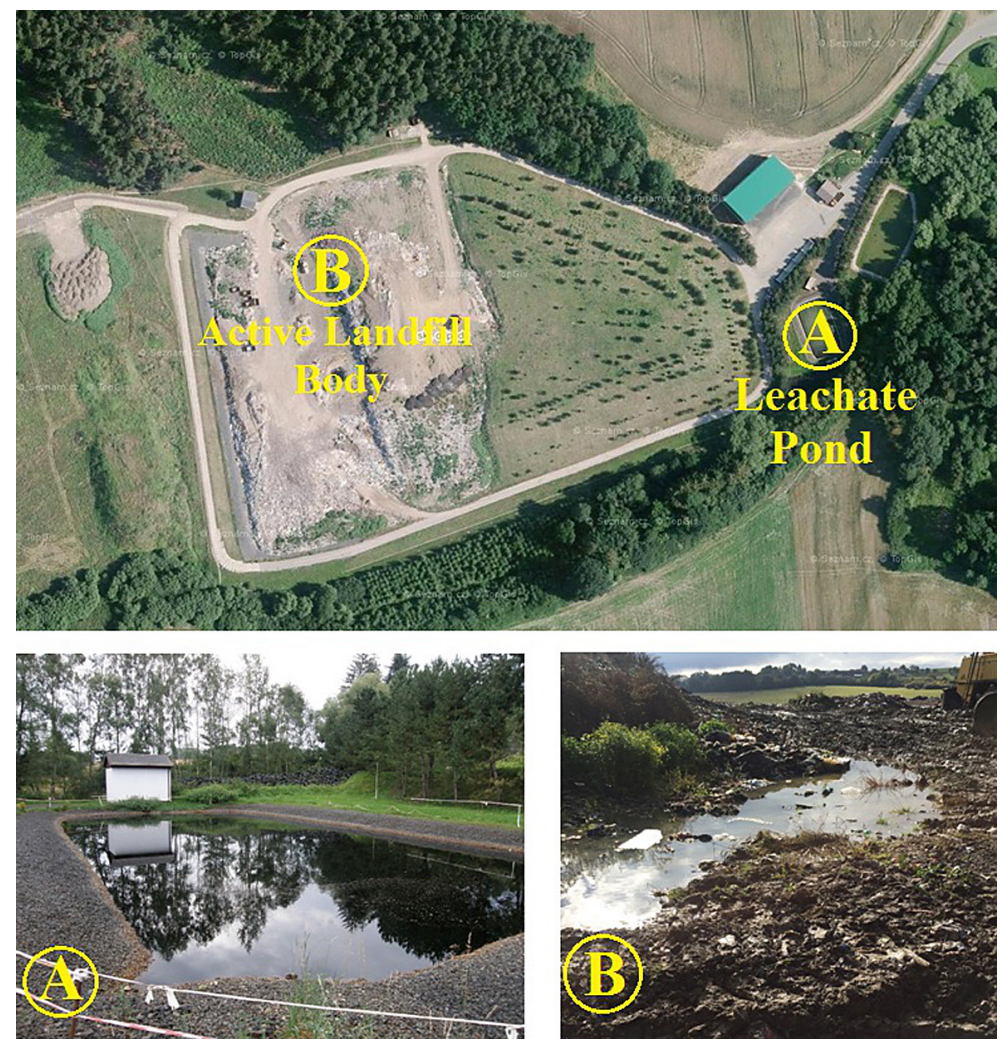

Figure 4. Sampling points; A - Leachate pond; B - Active landfill body

the germination index. The germination index is widely used for the assessment of phytotoxicity (Del Moro et al., 2014; Vaverková et al., 2017). On the basis of the studies conducted by previous authors, each leachate sample was diluted to give final leachate concentrations of $25 \%, 50 \%, 75 \%, 90 \%$ and $100 \%$. Each concentration of the dilution series was tested with two replicate samples. The test organisms were exposed to the leachate solutions for a total of 72 h (Vaverková et al., 2017). The seeds of Sinapis alba L. were germinated in Petri dishes with a $14 \mathrm{~cm}$ diameter on filter paper on the bottom. The setup of the experiment is presented in Figure 5. The hydroponic solution (distilled water with the following chemical ingredients $(\mathrm{mg} / \mathrm{L}): \mathrm{Ca}\left(\mathrm{NO}_{3}\right)_{2} \quad 0.8, \mathrm{KH}_{2} \mathrm{PO}_{4} \quad 0.2, \mathrm{KNO}_{3}$
$0.2, \mathrm{MgSO}_{4} 7 \mathrm{H}_{2} \mathrm{O} 0.2, \mathrm{KCl} 0.2, \mathrm{FeSO}_{4}$ 0.01, $\mathrm{pH}=5.2$ ) with tested liquid was added into each dish, and 15 healthy looking seeds of similar size were evenly spread onto the surface of the filter paper. The Petri dishes were covered by a glass cap to prevent loss due to evaporation and were stored in darkness, inside an Ecocell incubator $\left(\mathrm{t}=24^{\circ} \mathrm{C}\right)$. After $72 \mathrm{~h}$, the root length was measured (Vaverková et al., 2017).

\section{Calculations and data analysis}

The bioassays were performed in two replicates. The percent of root growth inhibition (RI) were calculated with the formula (Eq. 1) (Oleszczuk, 2010; Jośko and Oleszczuk, 2013; Vaverková et al., 2017):

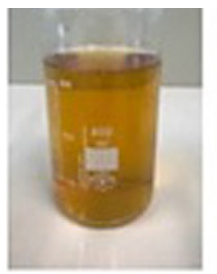

Samples

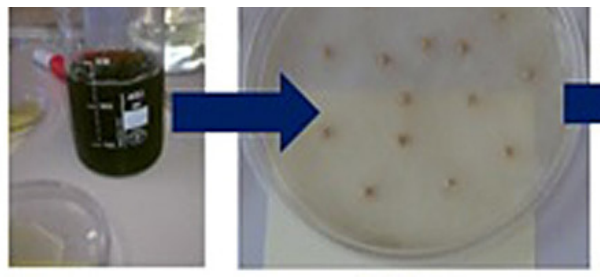

Start

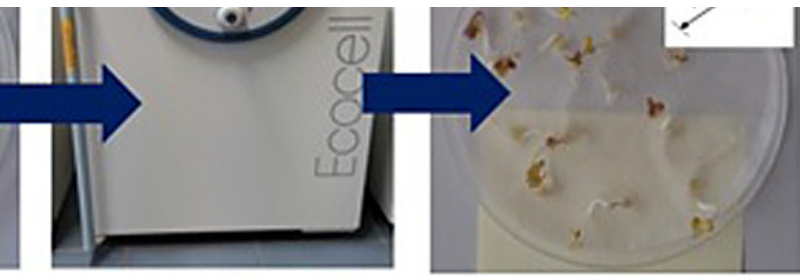

Incubation
End

Figure 5. The course of the experiment 


$$
\mathrm{RI}=(\mathrm{A}-\mathrm{B}) / \mathrm{A} \times 100
$$

where: $A$ means root length in the control;

$B$ means root length in the tested leachate sample (Vaverková et al., 2017).

\section{RESULTS AND DISCUSSION}

The development of the location in question is evident from the analysis of the historical map of the military mapping III (A), then the 1950 map (B) and the present map (C). The maps are depicted in Figure 6. Since the first mapping, the forest vegetation has spread, countryside mosaic has transformed, and a landfill was built (Heralová, 2017). The site of the Štěpánovice landfill was marked in red. The first stage of MSW Štěpánovice construction started in 1995. In 1998 and 2010, the landfill was expanded with $2^{\text {nd }}$ and $3^{\text {rd }}$ stages. At present, the fourth stage is under way and it will enable running the landfill until 2030.

In terms of the pedological conditions, the prevailing type of soil is mesobasic cambisol, or respectively dystric cambisol. The landfill lies in sand-loam to loam-sand sediment and on a rock called chert. There are sands, loam and gravel located at the landfill (Heralová, 2017). Figure 7 shows the location of the landfill in pedological (A) and geological (B) maps. The maps illustrate diverse types of soil (map A) and rock (map B).

$\mathrm{KAd}(\mathrm{RNm})$ dystric cambisol (RN modal); KAga' mesobasic ogleyic cambisol; KAa' mesobasic cambisol; RNt lithic ranker; $\mathrm{HNg}$ ' mildly oglyic brown soil; LUg ogleyic luvisol; PGm modal pseudogley; HNlg' luvic mildly ogleyic brown soil; GLm modal gley; 1 chert; 2 sandloam to loam-sand sediment; 3 alluvial sediments; 4 silicity

In terms of geomorphic ranking, the landfill site belongs to the Czech Highland province, Broun system, Švihov Highland unit, Radyn̆ Highland microregion, Kamýk Highland region. Štěpánovice and its vicinity are located in the mild warm climate MT 10 (very dry winters with short-term snow cover and a mildly warm course, dry and warm long-lasting summers). The average annual temperature is $8.0^{\circ} \mathrm{C}$ with

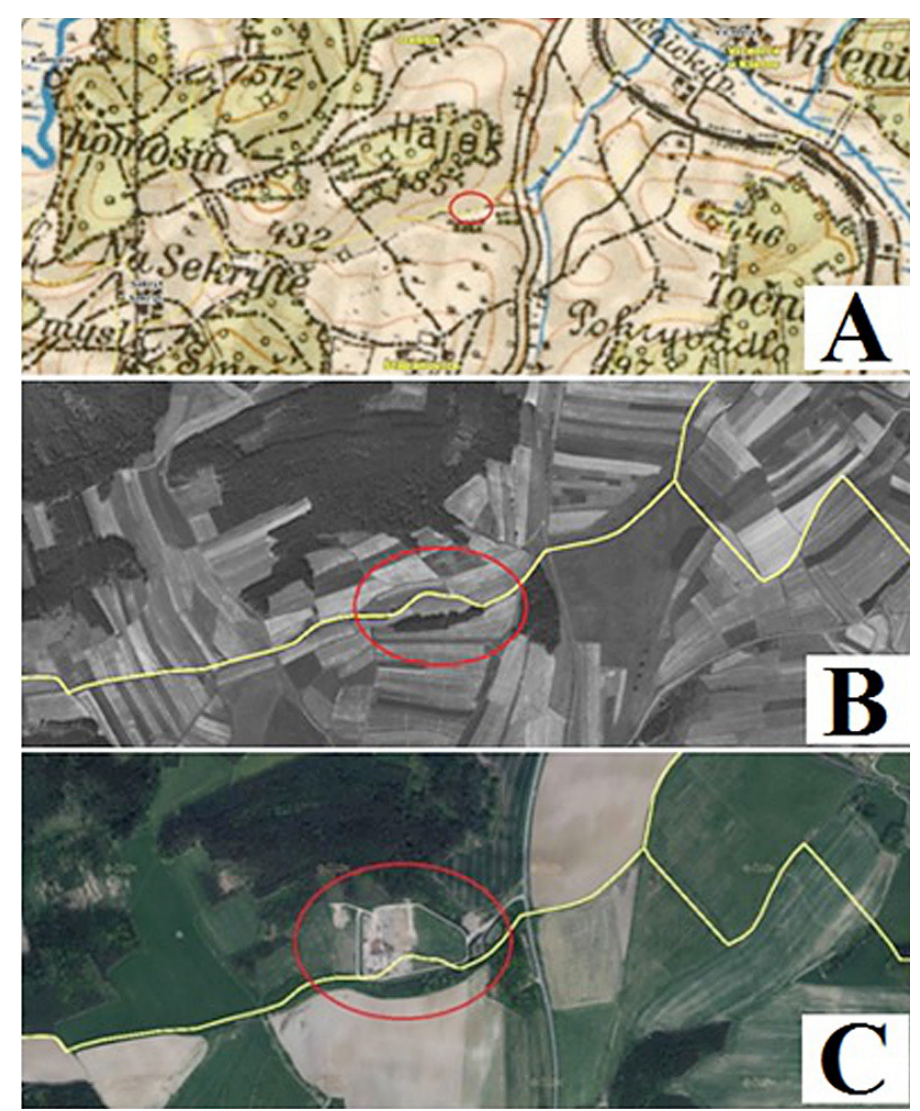

Figure 6. A Map III. military mapping, B Map 1950, C Map of the present condition (Heralová, 2017, modified Zloch, 2018) 


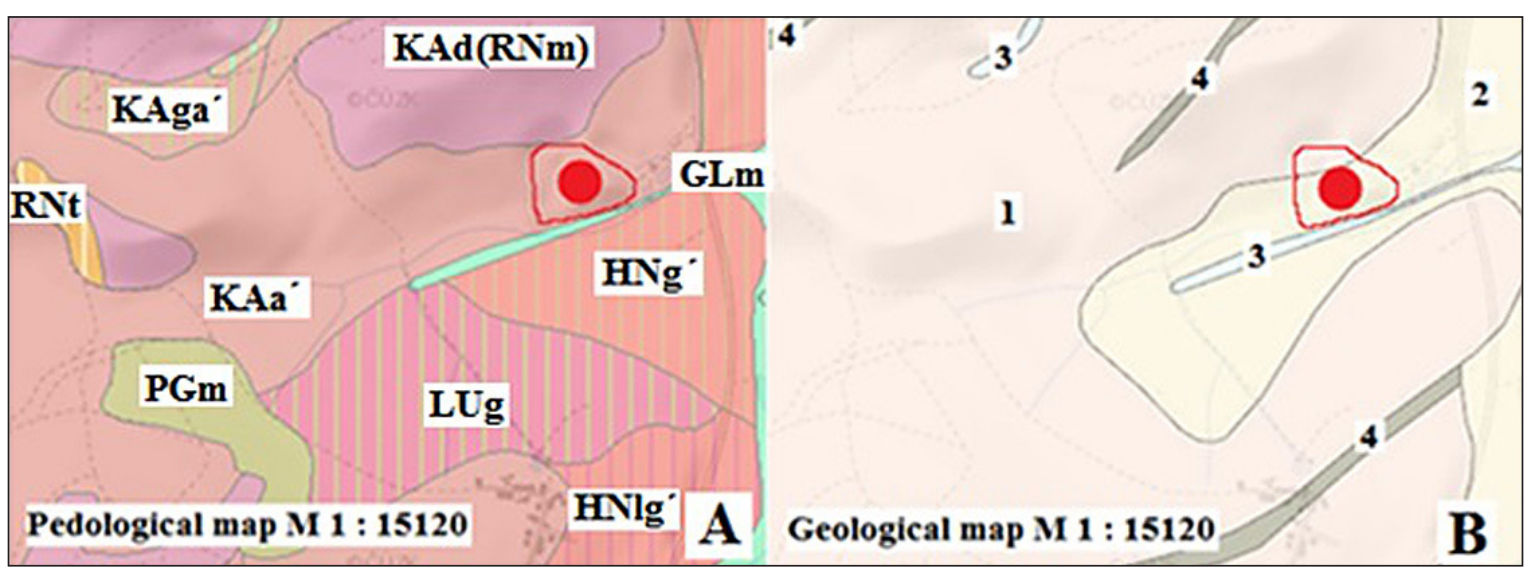

Figure 7. Geological and pedological map of the interest site

precipitation of $582 \mathrm{~mm}$ per year. The Úhlava river, Točnický brook, Štěpánovice pond and Nový pond are located in the vicinity of the landfill. The surrounding wetlands are classified in the territorial system of ecological stability as of supra-regional importance. The site falls under the biospherical unit of Central Bohemian deciduous forests. Several small areas under special protection surround the landfill: Stará Úhlava, Bělč, Bělyšov, Americká zahrada and Chudenická bažantnice. The landfill is located between the three protected landscape areas of Šumava, Brdy and Český les (Figure 8) (Heralová, 2017).

Green corridors and habitats are significant components of the territorial system of ecological stability surrounding the landfill. The location of the landfill, in respect to the components of territorial system of ecological stability, is demonstrated in Figure 9, the components of territorial system of ecological stability are distinguished in colour. The green corridor and habitats of regional and supra-regional significance are situated near the landfill (Heralová, 2017).
The technical and biological (forestry) reclamation of the landfill's first stage was completed in 2009. The forestry reclamation incorporated the landfill into the territorial systems of ecological stability. The biological reclamation was implemented by hydro-seeding, application of compost, and planting shrubs and trees. The biological reclamation layer was monitored up until 2012. Trees were planted, weeds eradicated and fertilisers reapplied repeatedly. The reclamation was successful as the mortality of planted trees was low. Figure 10 shows the pictures demarking the reclaimed areas of $1^{\text {st }}$ and $2^{\text {nd }}$ stage landfills between 2009 and 2017 (Vaverková and Adamcová, 2018).

\section{Characterization of the leachate}

Landfill leachate is one of the major sources of pollutions discharged into the environment. It is composed from a complex mixture of chemicals and handling typically involves treatment, either on-site or at a wastewater treatment (Vaverková et al., 2017). The physical and chemi-

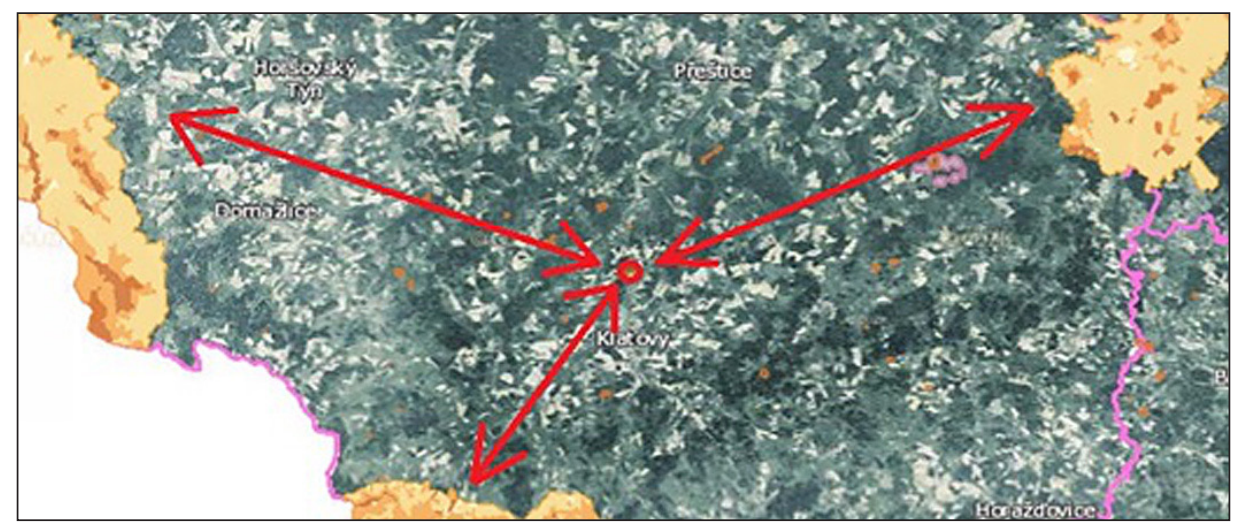

Figure 8. Map of protected landscape areas (Heralová, 2017) 


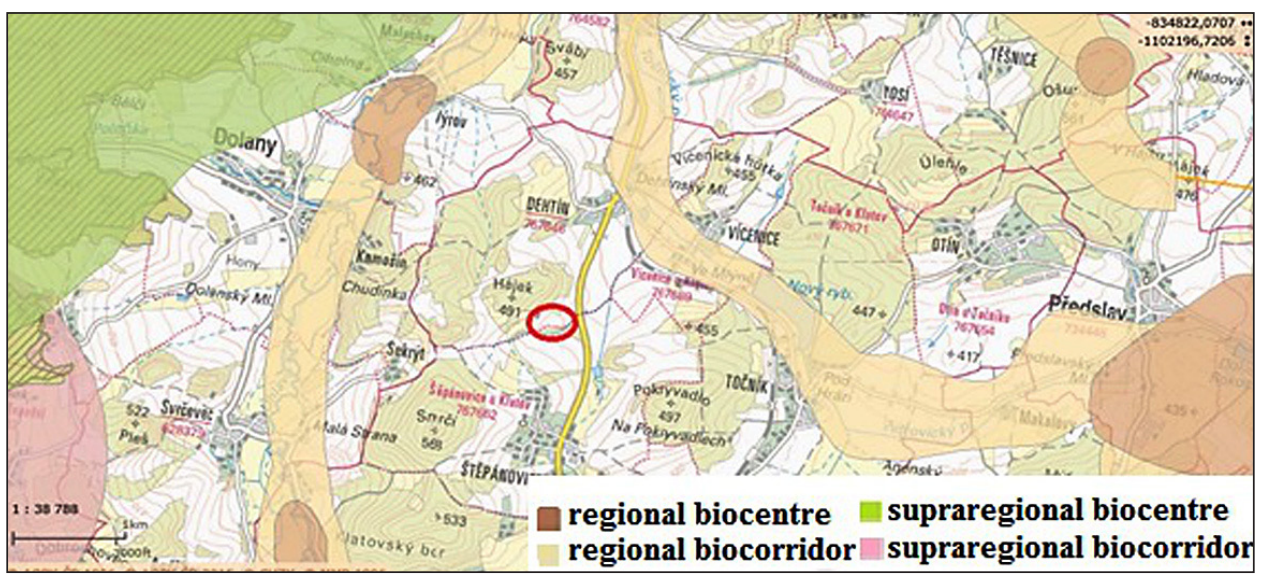

Figure 9. Map of the Territorial System of Environmental Stability (Heralová, 2017)
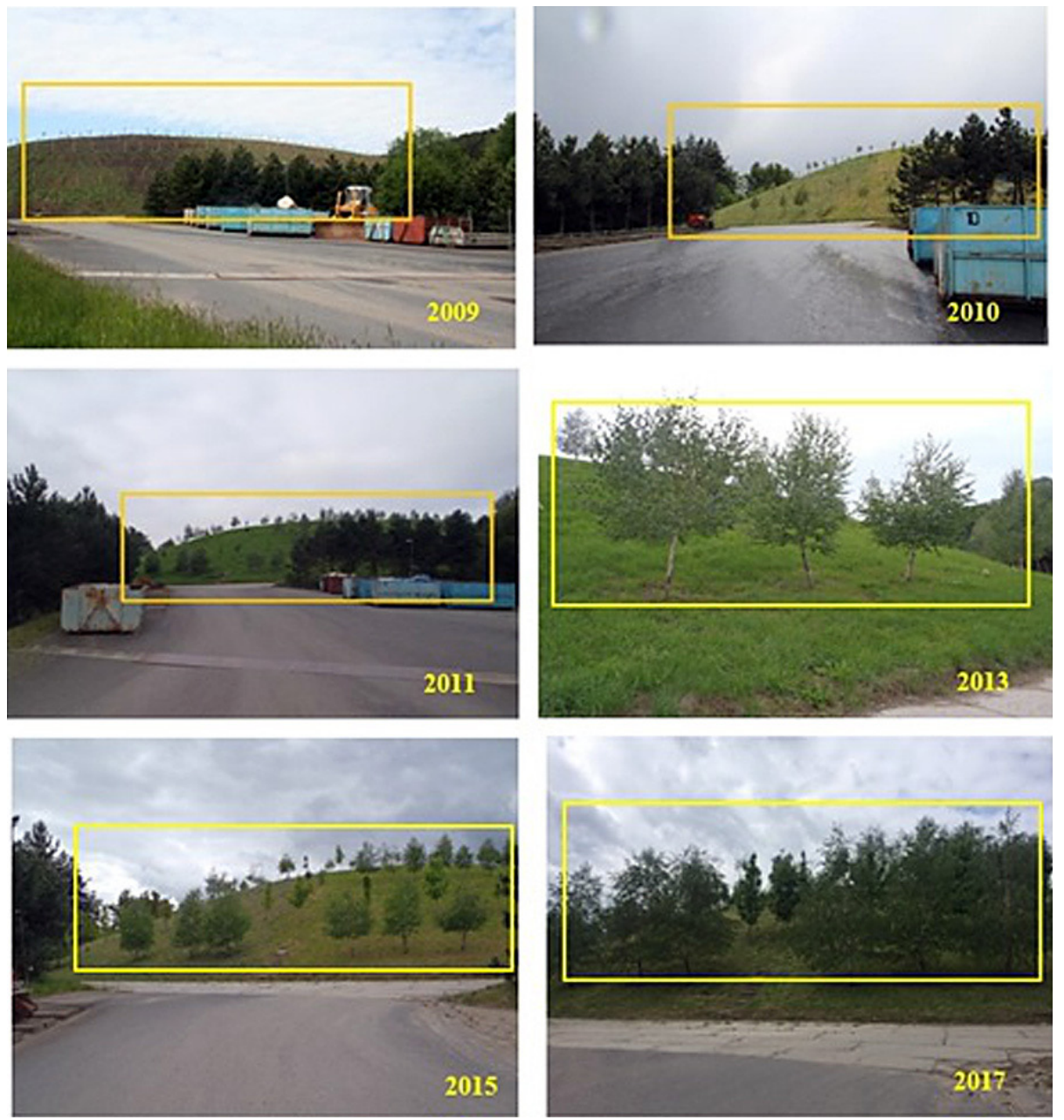

Figure 10. Reclaimed part of the landfill MSW Štěpánovice (Vaverková and Adamcová, 2018)

cal analysis of raw leachate sample is shown in Table 1. The leachate samples were analysed for $\mathrm{pH}$, electrical conductivity (EC), chemical oxygen demand (COD), other parameters and a series of metals $(\mathrm{Cd}, \mathrm{Hg}, \mathrm{Pb}, \mathrm{Zn}, \mathrm{Cr})$. Mean values for landfill leachate (month April - October 2016) are listed in Table 1.

\section{Results of growth inhibition of leachate samples}

The toxicity of the collected leachate samples was ascertained using the semi-chronic method opting for the seeds of Sinapis alba L. plant. The leachate concentrations were tested in all sam- 
Table 1. Physical and chemical characteristics of raw leachate

\begin{tabular}{|c|c|c|}
\hline Parameters & Unit & Values \\
\hline $\mathrm{pH}$ & - & 8.92 \\
\hline Temperature & ${ }^{\circ} \mathrm{C}$ & 4 \\
\hline $\mathrm{BOD}$ & $\mathrm{mg} / \mathrm{L}$ & 35 \\
\hline $\mathrm{COD}_{\mathrm{Cr}}$ & $\mathrm{mg} / \mathrm{L}$ & 489 \\
\hline $\mathrm{NH}_{4}{ }^{-}$ & $\mathrm{mg} / \mathrm{L}$ & 3.11 \\
\hline $\mathrm{NO}_{3}{ }^{-}$ & $\mathrm{mg} / \mathrm{L}$ & 198 \\
\hline $\mathrm{Cl}^{-}$ & $\mathrm{mg} / \mathrm{L}$ & ${ }^{*}$ \\
\hline $\mathrm{Cd}$ & $\mathrm{mg} / \mathrm{L}$ & ${ }^{*}$ \\
\hline $\mathrm{Hg}$ & $\mathrm{mg} / \mathrm{L}$ & 0.0001 \\
\hline $\mathrm{Pb}$ & $\mathrm{mg} / \mathrm{L}$ & $<0.05$ \\
\hline $\mathrm{Zn}$ & $\mathrm{mg} / \mathrm{L}$ & ${ }^{*}$ \\
\hline $\mathrm{Cr}^{6+}$ & $\mathrm{mg} / \mathrm{L}$ & ${ }^{*}$ \\
\hline $\mathrm{N}_{\text {total }}$ & $\mathrm{mg} / \mathrm{L}$ & ${ }^{*}$ \\
\hline $\mathrm{PO}_{4}{ }^{3-}$ & $\mathrm{mg} / \mathrm{L}$ & ${ }^{*}$ \\
\hline $\mathrm{SO}_{4}{ }^{2-}$ & $\mathrm{mg} / \mathrm{L}$ & ${ }^{*}$ \\
\hline $\mathrm{EC}$ & $\mathrm{mS} / \mathrm{m}$ & 522 \\
\hline
\end{tabular}

* immeasurable value

ples. Once the incubation term was over, the root length was measured for all seeds in the tested samples. The results were recorded and further processed. The obtained data was used to calculate the growth inhibition. The growth inhibition data for individual tested concentrations are processed into a graphic form (Figure 11-16). Likewise, the precipitation volume is provided for the periods under scrutiny.

The growth inhibition for a $25 \%$ leachate concentration (Figure 11) moved in positive values in the period under scrutiny, i.e. $25 \%$ leachate concentration shows an inhibitory effect on Sina- pis alba L. seeds. The growth inhibition figures for $25 \%$ concentration oscillated between $13.51 \%$ and $53.27 \%$. The average figure for growth inhibition under $25 \%$ was $36.51 \%$. The lowest values of growth inhibition were measured in the samples of leachate collected in June (13.51\%) and July $(26.46 \%)$, at the same time, the highest precipitation volumes over the whole monitored period were measured in these months. The volume of precipitation affected the leachate concentration and subsequently also the growth inhibition intensity for $25 \%$ leachate concentration.

The growth inhibition for 50\% leachate concentration (Figure 12) moved in positive values in the period under scrutiny, i.e. $50 \%$ leachate concentration shows an inhibitory effect on Sinapis $a l b a \mathrm{~L}$. seeds. The growth inhibition values oscillated between $10.19 \%$ and $72.94 \%$. The average value for growth inhibition for $50 \%$ concentration was $41.59 \%$. The lowest growth inhibition figures were measured for the leachate samples collected in June (20.05\%) and July (10.19\%), at the same time the highest precipitation volumes over the whole monitored period were measured in these months. The volume of precipitation affected the leachate concentration and subsequently also the growth inhibition intensity for $50 \%$ leachate concentration. The $50 \%$ concentration showed a greater growth inhibition on average than the $25 \%$ leachate concentration, by $5.08 \%$.

The growth inhibition for $75 \%$ leachate concentration (Figure 13) moved in positive values in the period under scrutiny, i.e. $75 \%$ leachate concentration shows an inhibitory effect on Sinapis

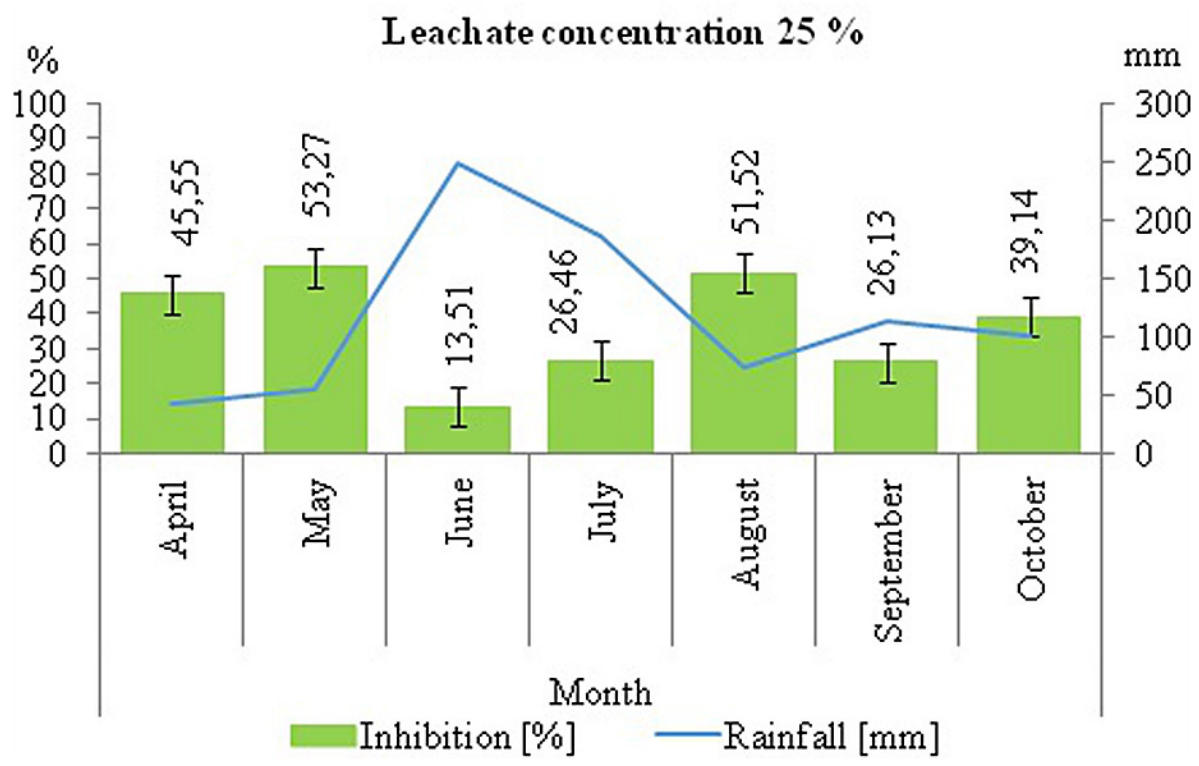

Figure 11. Inhibition and rainfall relationship at 25\% leachate concentration 


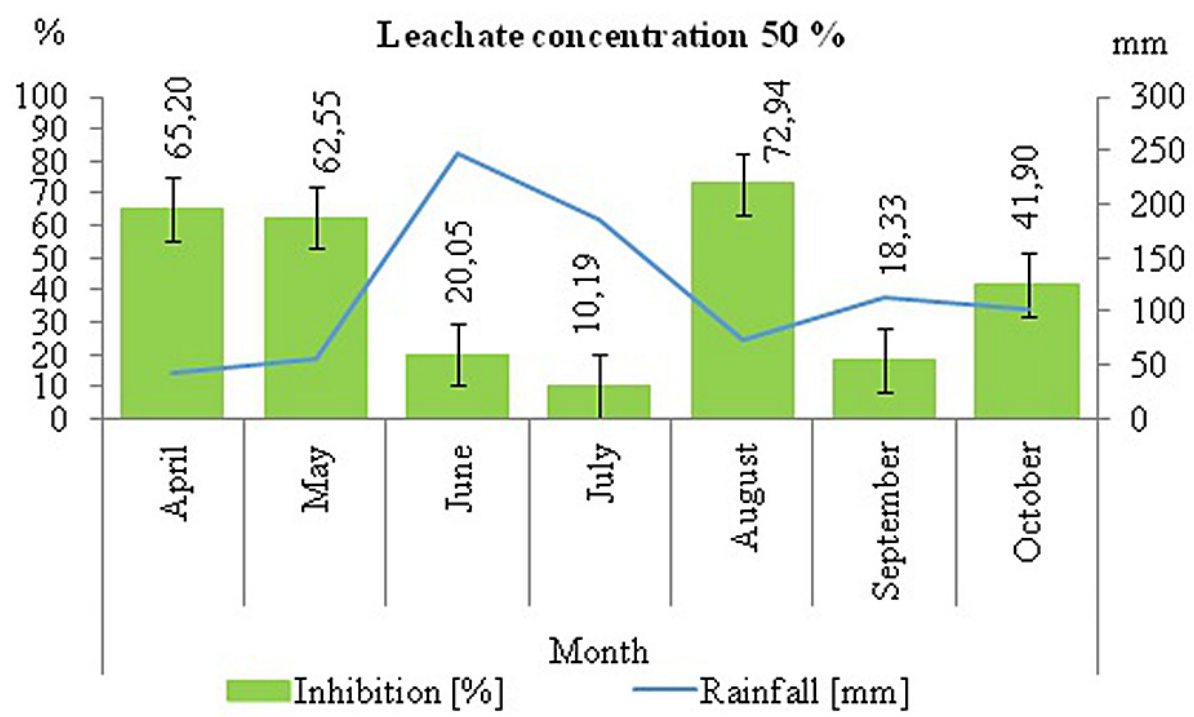

Figure 12. Inhibition and rainfall relationship at 50\% leachate concentration

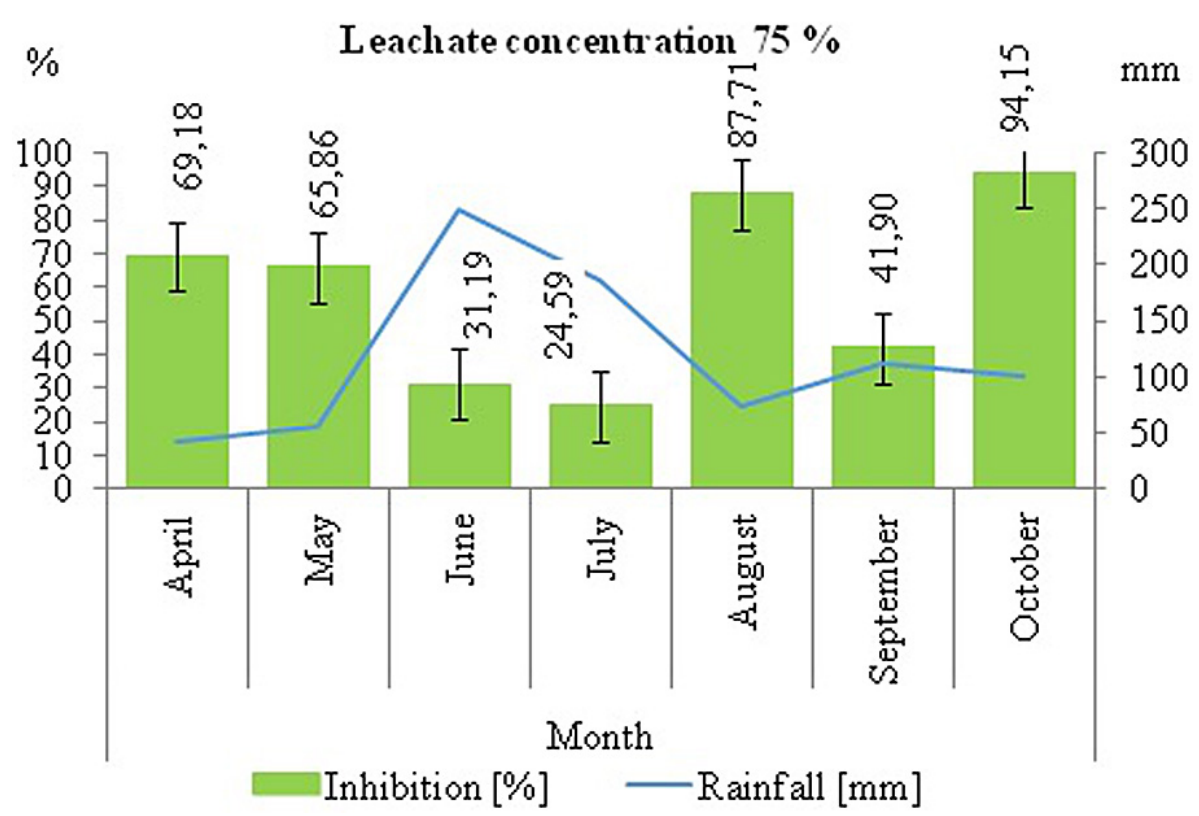

Figure 13. Inhibition and rainfall relationship at 75\% leachate concentration

$a l b a$ L. seeds. The growth inhibition figures oscillated between $24.59 \%$ and $94.15 \%$. The average value for growth inhibition for $75 \%$ concentration was $59.23 \%$. The lowest growth inhibition figures were measured for leachate samples collected in June $(31.19 \%)$ and July (24.59\%), and the highest precipitation volumes over the whole monitored period were measured in these months. The volume of precipitation affected the leachate concentration and subsequently also the growth inhibition intensity for $75 \%$ leachate concentration. The $75 \%$ concentration showed a greater growth inhibition on average than the $25 \%$ (by $22.72 \%$ ) and $50 \%$ (by $17.64 \%$ ) leachate.

The growth inhibition for $90 \%$ leachate concentration (Figure 14) moved in positive values in the period under scrutiny, i.e. $90 \%$ leachate concentration shows an inhibition effect on Sinapis alba L. seeds. The growth inhibition values oscillated between $38.64 \%$ and $98.44 \%$. The average value for the growth inhibition for $90 \%$ concentration was $67.36 \%$. The lowest growth inhibition figures were measured for the leachate samples collected in June (47.41\%) and July (38.64\%), 


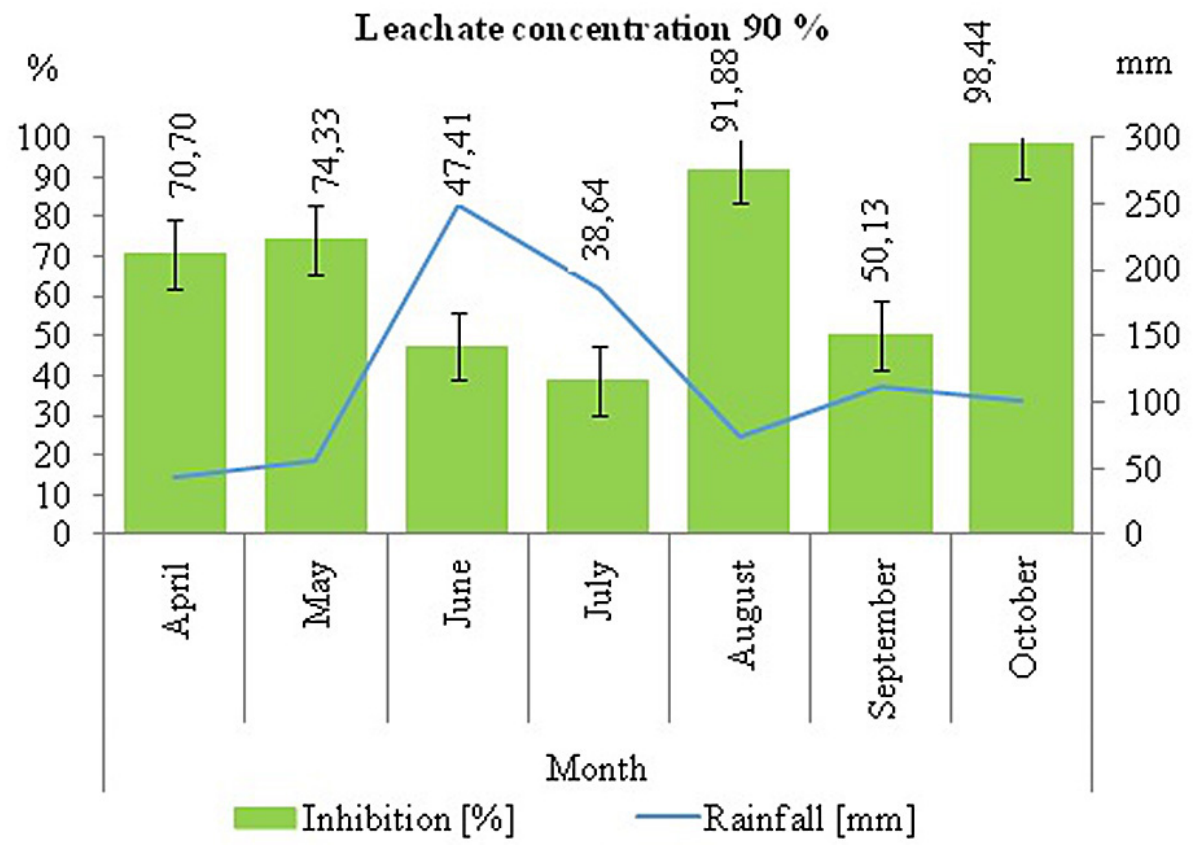

Figure 14. Inhibition and rainfall relationship at $90 \%$ leachate concentration

while at the same time, the highest precipitation volumes over the whole monitored period were measured in these months. The volume of precipitation affected the leachate concentration and subsequently also the growth inhibition intensity for $90 \%$ leachate concentration, just like with 25 , 50 and $75 \%$ concentrations. On average, the $90 \%$ concentration shows a greater growth inhibition than $25 \%$ (by $30.85 \%$ ), $50 \%$ (by $25.77 \%$ ) as well as $75 \%$ (by $8.13 \%$ ) of leachate concentrations.

The growth inhibition for $100 \%$ leachate concentration (Figure 15) moved in positive values in the period under scrutiny, i.e. $100 \%$ leachate concentration shows an inhibitory effect on Sinapis alba $\mathrm{L}$. seeds. The growth inhibition values oscillated between $43.91 \%$ and $99.48 \%$. The average value for the growth inhibition for $100 \%$ concentration was $73.26 \%$. The lowest growth inhibition figures were measured for the leachate samples collected in June (51.69\%) and July (43.91\%), while at the same time the highest precipitation volumes over the whole monitored period were measured in these months. The volume of precipitation affected the leachate concentration and subsequently also the growth inhibition intensity for $100 \%$ leachate concentration, just like with all the previously tested concentrations. The $100 \%$ leachate concentration showed the greatest overall growth inhibition (against 25\% concentration by $36.75 \%, 50 \%$ by $31.67 \%, 75 \%$ by $14.03 \%$ and by $5.9 \%$ in the case of $90 \%$ concentration).
Figure 16 shows the values of the growth inhibition for the leachate sample that was collected directly from the active body of the landfill as a one off, this water was tested at $25 \%, 50 \%, 75 \%$, $90 \%$ and $100 \%$ concentration. The growth inhibition for all monitored concentrations showed positive figures, all tested concentrations had an inhibiting effect on the tested seeds of Sinapis alba $\mathrm{L}$. The growth inhibition oscillated between $45.01 \%$ and $67.76 \%$. The growth inhibition increased along with the concentration. All concentrations showed significant growth inhibition.

The toxicity of a leachate is given not only by the character of the stored waste but also the amount of precipitation that reaches the active body of the landfill.

With increasing use of MSW landfills as the most widely utilized method of solid waste disposal, the potential contamination from municipal landfills has become a serious problem. Therefore, it is important to study the toxic effects of operating and/or closed landfills on plants, mammals and humans. As it was mentioned above, landfills can be a source of environmental pollution mainly through landfill leachate, which is wastewater highly saturated with various compounds leaching out of decomposing MSW (Ohe et al., 2004; Paskuliakova et al., 2018). Its composition is very complex because of the wide range of toxicants it contains (Cecilia and Junestedt, 2008, Paskuliakova et al., 2018). The biological testing has been used as an indicatory means of evaluating the 


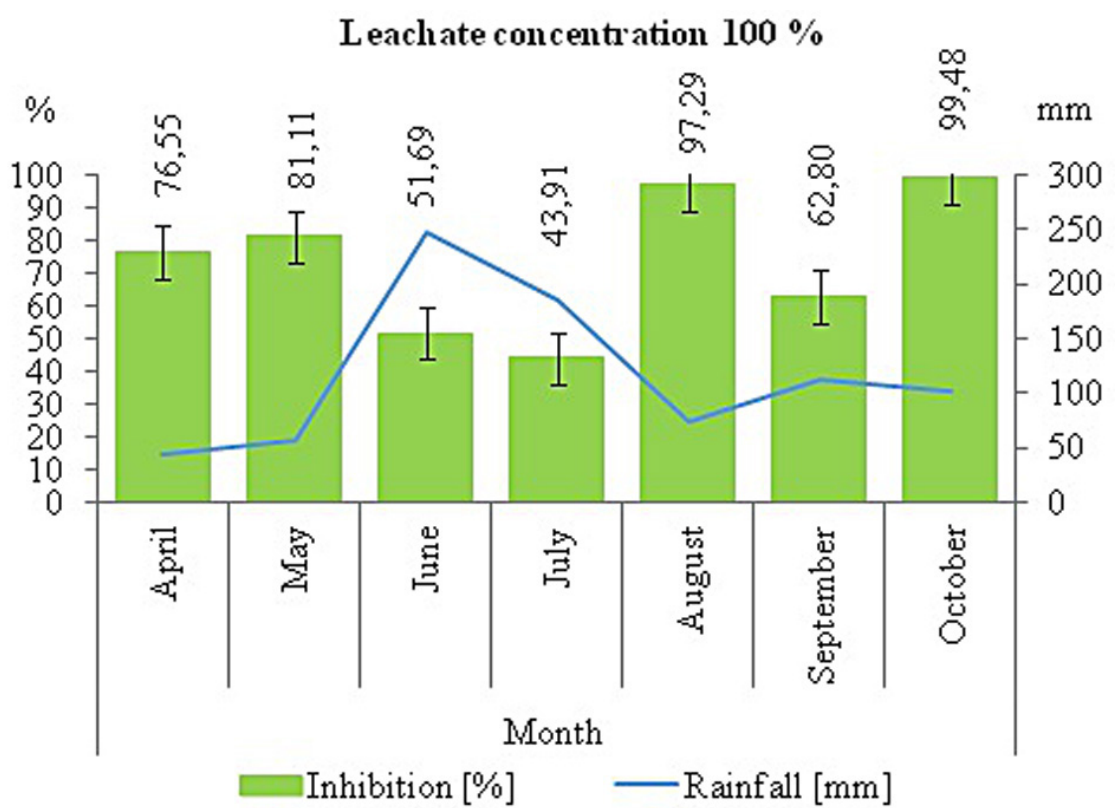

Figure 15. Inhibition and rainfall relationship at 100\% leachate concentration

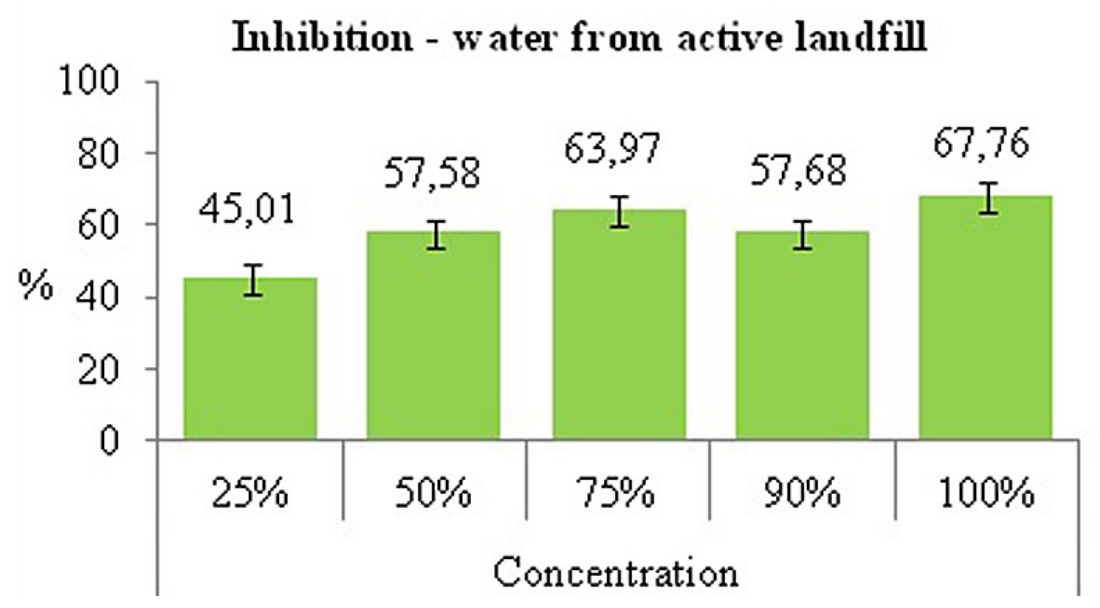

Figure 16. Inhibition of water from active landfill

toxicological impact of landfill leachate (Paskuliakova et al., 2018). The toxicity of raw landfill leachates varies greatly depending on the site and its environmental circumstances. Mostly, they are very toxic (Płaza et al., 2011; Paskuliakova et al., 2018; Zloch et al., 2018). Bortolotto et al. (2009) evaluated the toxic of landfill leachates from Southern Brazil using A. cepa as an indicator species. The inhibition of root growth and alkaline comet assay were used to assess the toxicity and genotoxicity potentials, respectively. The untreated leachate resulted in a significant inhibition of root growth. In the study carried out by Li et al. (2008) the physiological and genetic toxicity of the leachate, generated from Xingou Municipal Landfill in China, were investigated with Triti- cum aestivum (wheat) bioassay. The results from this study indicate that the lower leachate concentrations stimulated the germination and growth; however, the components of leachate from the landfill may be genotoxic in plant cells, and exposure to leachate in the aquatic environment may pose a potential genotoxic risk to organisms. In another study (Sang et al., 2006), examine the genotoxicity of leachate with the Hordeum vulgare. The results confirmed that components of leachate might be genotoxic in plant cells. The leachate toxicity also varies seasonally. As highlighted by Sang and Li (2004), seasonal difference in genotoxicity induced by leachate was observed and landfill leachates collected in different seasons vary in respect to their toxicity. 


\section{CONCLUSIONS}

Many studies have shown that the leachate from municipal solid waste landfills can be a source of contaminations. In this study it was observed that the contaminants in the leachate were diluted by rainfall, resulting in lower toxicity of leachate samples. The leachate at higher levels of concentrations heavily inhibited the plant growth, except for the leachate samples from June, July and September. In these three months, the rainfall was the largest so the toxicity of leachate samples was lower. Generally, the water at the landfill site is not toxic. The landfill itself is engineered, with bottom liner and leachate and landfill gas collection and treatment system. Therefore, leachate cannot find a path into the subsurface environment and migrate. The landfill has no direct and significant influence on the surrounding environment and water quality because: (i) the closed part of landfill is covered with an impermeable compact clay layer, geotextile membranes, nonwoven fabric and pulper products in order to prevent the rainwater from infiltrating the waste site and reaching the landfill base, (ii) the leachate from the landfill base is collected so that the leachate is entering the leachate pond, (iii) the evapotranspiration rate was increased by the biological recultivation (vegetative soil layer) planting of a vegetation cover over the landfill in order to reduce the leachate production.

\section{Acknowledgements}

This study was supported by the IGA - Internal Grant Agency Faculty of AgriSciences MENDELU No. TP 003/2018.

\section{REFERENCES}

1. Adamcová D., Radziemska M., Ridošková A., Bartoň S., Pelcová P., Elbl J., Kynický J., Brtnický M., Vaverková M.D., 2017. Environmental assessment of the effects of a municipal landfill on the content and distribution of heavy metals in Tanacetum vulgare L. Chemosphere 185, 1011 - 1018.

2. Bortolotto T., Bertoldo J.B., da Silveira F.Z., Defaveri T.M., Silvano J., Pich C.T. 2009. Evaluation of the toxic and genotoxic potential of landfill leachates using bioassays. Environmental Toxicology and Pharmacology, 28(2), 288-293.

3. Cecilia B.O., Junestedt C. 2008. Chemical characterization of landfill leachates -400 parameters and compounds. Waste Management, 28(10), 1876-1891.

4. Cuartas M., López A., Pérez F., Lobo A. 2017. Analysis of landfill design variables based on scientific computing. Waste Management, 71, 287-300.

5. Dajić A., Mihajlović M., Jovanović M., Karanac M., Stevanović D., Jovanović J. 2016. Landfill design: need for improvement of water and soil protection requirements in EU Landfill Directive. Clean Technologies and Environmental Policy, 18(3), 753-764.

6. Del Moro G., Barca E., Cassano D., Di Iaconi C., Mascolo G., Brunetti G. 2014. Landfill wall revegetation combined with leachate recirculation: a convenient procedure for management of closed landfills. Environmental Science and Pollution Research, 21 (15), 9366-9375.

7. El-Salam M. M. A., Abu-Zuid G. I. 2015. Impact of landfill leachate on the groundwater quality: A case study in Egypt. Journal of Advanced Research, 6(4), 579-586.

8. Ghosh P., Gupta A., Thakur I.S. 2015. Combined chemical and toxicological evaluation of leachate from municipal solid waste landfill sites of Delhi, India. Environmental Science and Pollution Research, 22(12), 9148-9158.

9. Gworek B., Dmuchowski W., Gozdowski D., Koda E., Osiecka R., Borzyszkowski J. 2015. Influence of a Municipal Waste Landfill on the Spatial Distribution of Mercury in the Environment PLoS One, 10(7).

10. Heralová K. 2017. Phytotocity leachate from landfills Štěpánovice. Mgr. Thesis, Mendel University, Brno.

11. Jośko I., Oleszczuk P. 2013. The influence of ZnO and $\mathrm{TiO} 2$ nanoparticles on the toxicity of sewage sludges. Environmental Science: Processes \& Impacts, 15(1), 296-306.

12. Koda E., Miszkowska A., Sieczka A. 2017. Levels of Organic Pollution Indicators in Groundwater at the Old Landfill and Waste Management Site. Applied Sciences, 7(6), 638.

13. Koda E., Osinski P., Sieczka A., Wychowaniak D. 2015. Areal Distribution of Ammonium Contamination of Soil-Water Environment in the Vicinity of Old Municipal Landfill Site with Vertical Barrier. Water 7(6), 2656-2672.

14. Li G., Yun Y., Li H., Sang N. 2008. Effect of landfill leachate on cell cycle, micronucleus, and sister chromatid exchange in Triticum aestivum. Journal of Hazardous Materials, 155(1-2), 10-16.

15. Li J., Wang Ch., Du L., Lv Z., Li X., Hu X., Niu Z., Zhang Y. 2017. Did municipal solid waste landfill have obvious influence on polychlorinated dibenzo-p-dioxins and polychlorinated dibenzofurans (PCDD/Fs) in ambient air: A case study in East China. Waste Management, 62, 169-176. 
16. Makarenko N., Budak O. 2017. Waste management in Ukraine: Municipal solid waste landfills and their impact on rural areas. Annals of Agrarian Science, 15(1), 80-87.

17. Nagarajan R., Thirumalaisamy S., Lakshumanan E. 2012. Impact of leachate on groundwater pollution due to non-engineered municipal solid waste landfill sites of erode city, Tamil Nadu, India. Iranian J Journal of Environmental Health Science \& Engineering, 9(1), 35.

18. Ohe T., Watanabe T., Wakabayashic K. 2004. Mutagens in surface waters: a review. Mutation Research, 567(2-3), 109-149.

19. Oleszczuk P. 2010. Toxicity of Light Soil Fertilized by Sewage Sludge or Compost in Relation to PAHs Content. Water, Air and Soil Pollution, 210(1-4), 347-356.

20. Palmiotto M., Fattore E., Paiano V., Celeste G., Colombo A., Davoli E. 2014. Influence of a municipal solid waste landfill in the surrounding environment: Toxicological risk and odor nuisance effects. Environment International, 68, 16-24.

21. Paskuliakova A., Mc Gowan T., Tonry S., Touzet N. 2018. Phycoremediation of landfill leachate with the chlorophyte Chlamydomonas sp. SW15aRL and evaluation of toxicity pre and post treatment. Ecotoxicology and Environmental Safety. 147, 622-630.

22. Płaza A., Nałe G., Ulfig K. 2011. Estimation of the environmental risk posed by landfills using chemical, microbiological and ecotoxicological testing of leachates. Chemosphere, 82(7), 1017-1023.

23. Sang N., Li G., Xin X. 2006. Municipal landfill leachate induces cytogenetic damage in root tips of Hordeum vulgare. Ecotoxicology and Environmental Safety, 63(3), 469-473.

24. Sang N., Li G. 2004. Genotoxicity of municipal landfill leachate on root tips of Vicia faba. Mutation Research/Genetic Toxicology and Environmental Mutagenesis, 560(2), 159-165.

25. Shu S., Zhu W., Wang S., Wang Ch., Ng C.W.W., Chen Y., Chiu A.C.F. 2018. Leachate breakthrough mechanism and key pollutant indicator of municipal solid waste landfill barrier systems: Centrifuge and numerical modelling approach. Science of The Total Environment, 612, 1123-1131.

26. Vaverková M.D., Zloch J., Adamcová D., Radziemska M., Vyhnánek T., Trojan V., Winkler J., Đorđević B., Elbl J., Brtnický M. 2017. Landfill Leachate Effects on Germination and Seedling Growth of Hemp Cultivars (Cannabis sativa L.). Waste and Biomass Valorization, https://doi. org/10.1007/s12649-017-0058-z

27. Vaverková M.D., Adamcová D. 2018. Case study of landfill reclamation at Czech landfill site. Environmental Engineering and Management Journal, In print.

28. Wolny-Koładka K., Malinowski M. 2015. Assessment of the microbiological contamination of air in a municipal solid waste treatment company. Ecological Chemistry and Engineering A, 22(2), 175-183.

29. Zloch J., Vaverková M.D., Adamcová D., Radziemska M., Vyhnánek T., Trojan V., Đorđević B., Brtnický M. 2018. Seasonal alterations of landfill leachate composition and toxic potency of leachate for White mustard (Sinapis alba L.). Acta Universitatis Agriculturae et Silviculturae Mendelianae Brunensis, 66(1), 235-242. 